\title{
The Late Iron Age Bear-Tooth Pendants in Finland: Symbolic Mediators between Women, Bears, and Wilderness?
}

NORA KIVISALO

University of Turku

\begin{abstract}
In the article I discuss the different functions and meanings of bronze bear-tooth pendants in the Finnish Late Iron Age (800-1150/1300 CE). I first focus on an analysis of the pendants in terms of archaeological methodology: chronology, typology and find context. The second focus of attention, and in this article the most important one, is on the interpretation of these pendants. They are usually interpreted as magical items, amulets. In my opinion this is not the only possible interpretation. I suggest that the pendants can be interpreted as magical or religious, but that their possible protective use as amulets does not exclude other functions, such as a decorative and/or social one. I emphasise the possibility that bear-tooth pendants may be linked to a symbolic form of expression involving the idea of control of the forest and wilderness. Finnish folk tradition and mythology point to a metaphoric and metonymic relationship on the one hand between the bear and the wilderness, on the other the bear and women. The bronze bear-tooth pendants - possibly worn only by women - may have carried a symbolic message of control over the wilderness; this control could have been mythology-based and practised by ritual acts; at the same time it could also take the form of concrete acts, such as utilization of the wilderness: a fur-based economy and control over the fur trade.
\end{abstract}

Keywords: bear-tooth pendant, Iron Age, Finland, cognitive archaeology

In Finland, more than a hundred bear-tooth pendants are known. The regional distribution of bronze bear-tooth pendants is concentrated in southwest Finland. The majority of these finds are from cremation cemeteries, but some have been found in inhumation graves. Cemeteries containing bear-tooth pendants indicate continuity and prosperity. Some of these cemeteries and graves contain rich combinations of grave goods, and some of their artefacts can be interpreted as status objects. Some artefacts are also evidence of extensive foreign trading links. There are examples of wealthy 
women's graves with the bronze bear-tooth pendants; in fact, all the inhumation graves found so far with these items belonged to women. Bear-tooth pendants are approximately five to seven centimetres in length, and their upper part imitates bronze wiring. The pendants are curved in form, and seem to imitate real bear tooth. Actual, organic bear-tooth pendants were widely used in historical times, but some genuine bear-tooth pendants are also known from Iron Age contexts.

Rather than analyzing the chronology, typology or stylistic elements of bear-tooth pendants, or considering other traditional archaeological questions, it is more interesting and important to understand their symbolic meaning in the past (e.g., Shanks \& Hodder 1995; Eldorhagen 2001, 180-5). The archaeological material, however, can be a starting point for questions concerning for instance the forms of human intellectual and symbolic behaviour and the products of the human mind. The problem is how to distinguish between on the one hand practical, functional or technological artefacts, on the other 'non-practical items' connected with religion, ideology or cosmology. In particular it has been noted that the application of the modern ritual-secular dichotomy to earlier times has led to misleading interpretations. In modern western culture, the practical and the symbolic, as well as the ritual and the secular, are conceived as opposing categories (Brück 1999, 314, 322-4; Carlie 2001, 198-210). Symbols, however, also have pragmatic, social functions; in practice, it seems impossible to distinguish between them in material culture (e.g., Leach 1976, 14-5; Shanks \& Hodder $1995,17)$. Instead of maintaining modern binary oppositions, according to Joanna Brück $(1999,327)$, the fundamental issue should be, what can past actions tell us about the nature of prehistoric rationality?

The production and use of the bear-tooth pendants, and their possible meanings, have to be approached in context. Traditions, conceptions and beliefs, as well as symbolism, usually present continuity, they resist time; at the same time, however, they undergo constant temporal, spatial and social change (Shanks \& Hodder 1995). Rather than reconstructing either the entire pre-Christian religion or particular beliefs, my aim here is to trace possible mental models or structures, the worldview and rationality of Late Iron Age societies (see e.g., Carlie 2001, 200; Näsström 2002, 53). Questions raised by the archaeological data can be analysed with the help of other disciplines studying cultures. Cognitive analysis and contemporary theories (such as those which have arisen in the study of religion) offer methodological and theoretical tools for interpreting the archaeological material. 


\section{The Context of the Finds}

The bronze bear-tooth pendants occur mainly in south-western Finnish cremation cemeteries, but a few of them have been found from inhumation cemeteries (Map 1). The bronze bear-tooth pendants could be used singly, but some inhumation graves show that they were worn as a set, hanging at the waist (Figure 1). The inhumation cemeteries which contained these bronze pendants had a rich combination of grave goods. One of the richest examples was the female inhumation grave (number 27) at the Kirkkomäki burial ground in the Turku area. Radiocarbon dating with calibration suggests a dating between 1020 and 1160 (Jäkärä 1997, 17; Riikonen 2005, 52-3; see also Asplund 2005, 18), but in the cremation cemeteries the datings of these pendants are mostly earlier. I assume that the earliest types appeared in the Turku area in the tenth century (Kivisalo 2006). Cremation cemeteries, however, are problematic, as they cannot be analysed as a closed context.

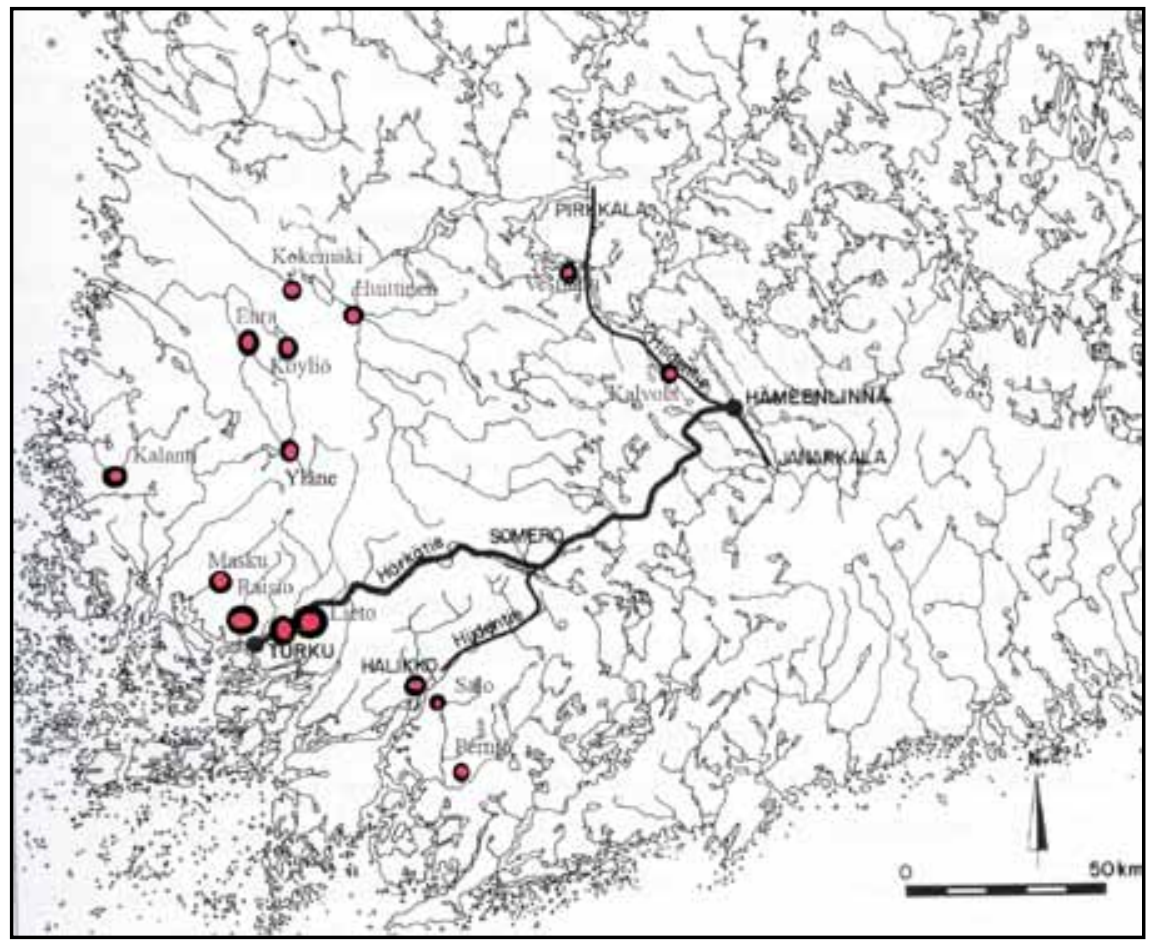

Map 1. Occurrence of bronze bear-tooth pendants in southwest Finland and the oldest trading routes, the Häme Oxen Road (Hämeen Härkätie) and the Hiisi Road (Hiidentie), following Jaakko Masonen (1989). 
All known inhumation graves which have contained bronze tooth pendants have been identified as female burials, although not all of these graves can be considered closed contexts. In addition to the hundred pendants known from the Finnish mainland, bear-tooth pendants are also known from other areas. Ten bronze bear-tooth pendants have been discovered in the Late Iron Age Liv area in Latvia, mainly from cemeteries - all of them in female contexts. The Latvian pendants formed part of chest-chain arrangements. There is even one case where a bronze bear-tooth pendant and an organic bear-tooth pendant were combined as part of female chain holders; these in turn were attached to shoulder brooches, the so-called tortoise brooches (Ciglis et al. 2001, 30). There is also one pendant from Hammarland in the Åland Islands and one from Gråträsk in Nothern Sweden (Kivikoski 1965, 23; Serning 1965, 387-96; Zachrisson 1994, 92-3).

It seems possible that the bronze bear-tooth pendants have a Finnish origin. A more important question than their place of origin, however, is why the pendants occur, in addition to southwest Finland, in the Livs region; not in Estonia, with which the Finnish mainland had many lively links during the Iron Age. On the other hand, organic bear-tooth pendants have been found abundantly in Estonia as well as its neighbouring areas (Luik 2001, 12-3).

The Liv culture flourished in the Late Iron Age (10th-12th century). During this period it played an active role in exchange and trade routes as well as military activities, based on a specialized economy (Snë 2005, 169-85; see also Ciglis et al. 2001, 30). It is specifically this involvement in extensive long-distance trade that has been seen as the main factor giving the Liv material culture its relatively open and diverse character (Snë 2005, 180-1). Among the Livs it was typical, especially for women, to attach a quantity of various everyday utensils, amulets and ornaments to their costumes. These dress accessories, such as the tortoise brooches, were adapted from other areas to fit local tastes (see Katalog 1896, 67, Abb. 26: 15, 16; Luik 1998, 15; Snë 2005, 180-1).

Some scholars have discussed the common features shared in the 11th12th century by the area inhabited by the Livs and southwest Finnish sites. For example in Raisio such material features include the large numbers of clay loom-weights and cupola ovens and a lead-bronze ingot, as well as the bronze bear-tooth pendants (Suhonen 1998, 71; Pihlman 2005, 207-23; Kivisalo 2006). The connections between the Liv area and southwest Finnish sites are also visible in the small round convex brooches and female bronze-spiral decorated aprons (Suhonen 1998, 74; Riikonen 2005, 33). Sirkku Pihlman 
(2005) has suggested three possible forms of communication in the Baltic Sea area. The first is the professional sphere of contacts among merchants and missionaries; second, the sphere of local and strategic contacts; and finally the sphere of deep traditions and extended kinship. These aspects of communication have to be taken into consideration in accounting for the occurrence of bronze bear-tooth pendants in both areas.
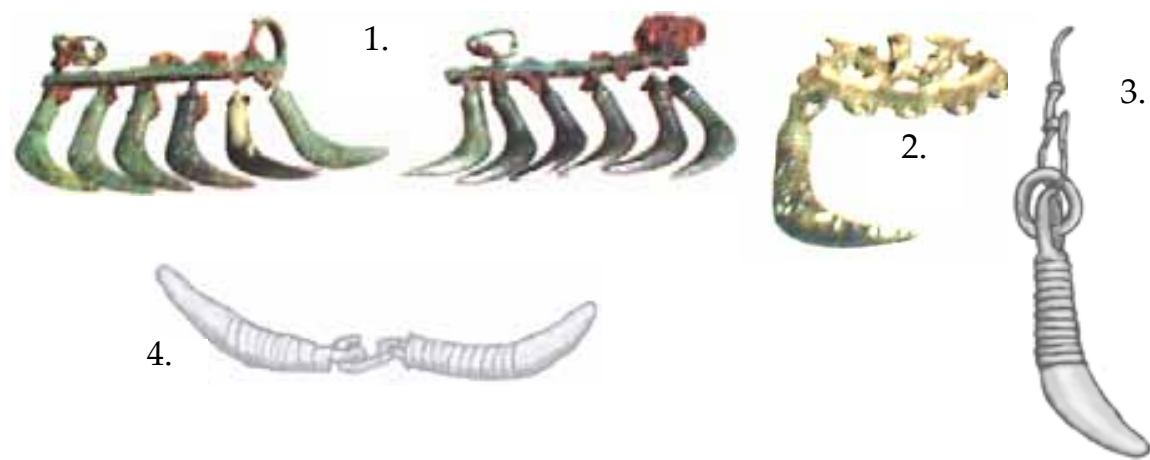

Figure 1. Use of bronze-tooth pendants in a costume. (1) Bronze pendants as a set on the waist have been found at the Kirkkomäki cemetery in Turku. (2) A single pendant attached to a chain holder (Turku, Kirkkomäki). (3) A bear-tooth pendant on a chain. Another example of a single pendant in a chain arrangement on the breast has been found in an inhumation grave in Kalvola, Häme. One pendant was also placed in the double grave of a man and a woman (Masku, Humikkala). (4) Two pendants joined together (Lieto, Merola). (Kivisalo 2006.)

\section{Earlier Interpretations of Bronze Bear-Tooth Pendants}

The bronze bear-tooth pendants have been interpreted mainly as amulets and thus connected to protective magic (Kivikoski 1965, 22-35; see also Vahter 1932, 40-9). On the basis of certain Finno-Ugric ethnological analogies - especially from Inkeri and the Mordva area in Russia - some pendant sets including bronze bear-tooth sets have been interpreted as belonging to decorated loincloths (Fi. kaatterit) (Vahter 1932; Kivikoski 1965, 24, 26-7, Lehtosalo-Hilander 1992; Salo 2006, 177, 182). While some bronze beartooth and bell-pendant sets have been hung from the waist, archaeological evidence of such loincloths is still missing (see Riikonen 2002).

Some scholars have regarded both bronze and organic bear-tooth pendants as pagan emblems or symbols used in Finland in the Late Viking Age and the period of christianization, the so-called 'Crusade' Period, during the 
transition process from paganism to Christianity. In some cases they have even been interpreted as analogous to the Scandinavian Thor's hammer pendants (see Kivikoski 1971, 97; Purhonen 1998). The context of the finds suggests that various pendants were most popular in the 11th century (see Kivikoski 1951; Koivisto 1991, 70-8).

The oldest pendants are naturalistic in form, possibly intended as imitations of real bear-tooth, but later their form and style is gradually transformed into a more curved and abstract expression (Figure 2). Henrik Asplund $(2005,15)$ has argued that this may indicate the idea of both teeth and claws as an expression of the whole animal, or even a general idea of the wild animals of the forest, of which the most important icon was the bear. Because of the pendant's form and the occurrence of Late Iron Age organic bear-tooth pendants, the bronze pendants have been connected with bear's teeth. This interpretation is supported by Finnish mythology and folklore relating to bears (Sarmela 1972, 1994a; Asplund 2005, 15).

Asplund $(2005,13-30)$ has associated bronze bear-tooth pendants with Finnish bear mythology and folklore, with its gender emphasis. He has strongly underscored the female role as mediator between the domesticated sphere (home, farm and household) and the outside world. Asplund (2002, 19) suggests that the bronze bear-tooth pendants were probably intended for women; organic bear teeth and claws, in contrast, do not seem to be gender-related. The same phenomenon can be seen at different times in many cultures, including Finno-Ugric and Indo-European cultures, in both archaeological material and ethnographical sources (Kivikoski 1965, 23-6; Tõnisson 1974, 122; Zarina 1988, 56; Ciglis et al. 2001, 31).

Jaana Riikonen $(2005,31-72)$ has discussed the bronze bear-tooth pendants as well as the bell-pendant sets and aprons, all of which were worn around the waist, for the most part on the basis of ethnological analogies. She notes that these pendants and decorated aprons have been found only in a few female graves, but are nevertheless more than decorations or markers of wealth. According to Riikonen, these items were closely connected with securing fertility and with protective magic, possibly also with certain women's special role in fertility rites. Ensuring fertility, Riikonen argues, was especially important in agricultural communities; thus the pendants belonged to the costume of a woman of childbearing age and were worn close to the genital area. (Riikonen 2005.) 

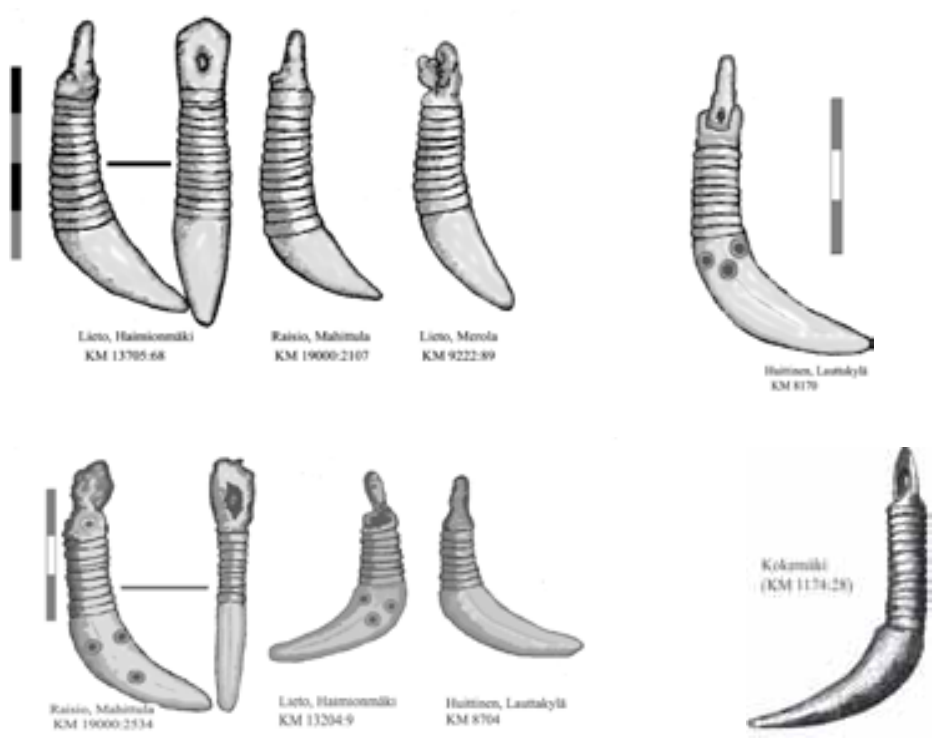

Figure 1. Use of bronze-tooth pendants in a costume. 1. Bronze pendants as a set on the waist have been found at the Kirkkomäki cemetery in Turku.

\section{Bear Remains in Different Archaeological Contexts}

Bear-claws have been discovered in Iron Age cemeteries of Finland and Scandinavia (Kivikoski 1965, 27; Petré 1980; Formisto 1996, 84-5; Hårding $2002,217,219)$. Especially in Sweden they have been connected with the increasing role of the fur trade, and with the display of status - if they are interpreted as the remains of furs. They have also been seen as amulets (Petré 1980, 8; Bennett 1987, 118; Mansrud 2002). In Scandinavia, bear remains have also been found in sacrificial sites (Näsström 2002, 54, 57; see also Sarkamo 1970, 46; 1984, 306; Carlie 2001, 201). Bear claws discovered in the foundations of buildings also occur in medieval and later contexts. In such cases they have been interpreted as the remains of so-called 'foundation deposits' (Finnish perustuskätkö) (Herva \& Ylimaunu 2004, 24; see also Tupala 1999, 48; Vuorinen 2003, 146; Hukantaival 2006).

Organic bear-tooth pendants are common in areas adjacent to Finland. Examples are known from Novgorod, Estonia and Latvia, where they have been dated to the 11th-13th century (Tõnisson 1974, 122, Taf. XIX:10, XXV:4, XXVI:2; Uino 1997, 260, 365). Some pendants have been unearthed in excavations of the medieval town area of Turku: both organic and bronze tooth 
pendants, for instance, have been found within the same medieval building. This bronze pendant may have originated from an Iron Age cemetery (Valonen 1958, 41, 43, 39; Pukkila 1999, 42).

Bear teeth occur also in churches. These finds are mainly from bearskins, which have been considered as sacrifices for the church (Finnish taljauhri) (Korhonen 1982, 96-121; Hiekkanen 1988, 67). There are also some examples of organic bear-tooth pendants and bear teeth in churches (Hiekkanen 1988, 67; Paavola 1988, 29, 33; Hiekkanen 1997, 65). The traditional use of organic bear-tooth pendants and other parts of the bear (teeth, bones, bile and so on) has persisted almost down to the present (see Pentikäinen 2005, 92-5). Such objects are included in various ethnological collections in museums, and considerable information is available as to their use. In the Sámi area, for instance, pendants of this kind were collected during the 20th century (see Leppäaho 1937, 134-44).

\section{Overview of the Finnish Bear Tradition}

The ancient bear rites and beliefs of European, Asian and North-American hunting peoples share many similarities, leading some scholars to propose a common northern bear cult or bear religion (Sarmela 1994a, 209-10; Edsman 1994, 13-4). The archaeological evidence suggests that the roots of the bear cult are derived from the Palaeolithic era. In particular MiddlePalaeolithic cave finds point to the sacralisation of the bear; one the most significant of these is the Chauvet Cave in southern France (e.g., Miettinen 2006, 117-26).

The Finnish myth of the origin of the bear belongs to a widespread transnational myth complex (Haavio 1967). There survive some descriptions of Finnish bear rites (Haavio 1967, 37-41; Sarmela 1972, 1994a). In 1640, Bishop Rothovius condemned the Finnish bear rites, in which 'men drank beer from a bear skull and growled like bears, believing this would bring them luck in hunting' (Haavio 1967, 15; Pentikäinen 2005, 107-9). Especially in Finno-Ugric cultures bear-hunting was strictly ritualized, similarly to cleansing rituals, and included taboos, such as avoiding women before hunting. The use of metaphorical language and propitiating expressions addressed to the bear was also part of the rituals (Harva 1933, 272; Vuorela 1981, 141; Tarkka 1994, 72-3; Ylimaunu 2002, 118-9). The feast for a killed bear (the Finnish word, peijaiset, refers to 'a funeral') was an important part of the ritualization (Haavio 1967, 19-20; Nirvi 1982, 126; Edsman 1994; Pentikäinen 2005, 62-5). The slaughtered bear was celebrated in a 'wedding' between 
a woman and the bear, during which the bear's teeth were detached and shared among the men - they remained as a sign of community among those who had participated in the feast (Salminen 1914; Haavio 1967, 19-20; Sarmela 1994b, 40-1). The bear's meat was eaten; the bones were then carefully buried in a particular order, and the skull, which was believed to be the home of the soul, was placed high up in an old pine tree. This pine, the kallohonka ('skull pine'), was probably a symbol of the world tree. Placing the skull high in the tree meant replacing the soul in the sky whence it had originated (Haavio 1967, 31; Edsman 1994, 50; Pentikäinen 2005, 111). The bear would eventually return from the sky and reincarnate (Haavio 1967, 37; Sarmela 1994a, 220-2). The bear's death was explained as an accident, for which the hunters were not responsible (Sarmela 1994b, 40).

One interesting point is derived from a manuscript recorded at the end of the 17 th century, the so-called 'Viitasaari text'. The text describes a particular custom of the Viitasaari chapel parish in Kivijärvi, whereby the church bells were rung when a bear skull was removed (Salminen 1914; Sarmela 1994b, 40-1). Another representation of the bear tradition is seen in the numerous bear graves found throughout Scandinavia - mainly in the Sámi area, but also in Finland - and dating to as late as the 19th century (Zachrisson \& Iregren 1974; Sarmela 1994a, 219). The bear also occurs in personal, family or village names (Karhu, Ohto, Osma) and in place-names in Finland and Karelia (and also in Estonia). And there are records and reminders of skulltrees in such place-names as Pääsaari ('Head Island') and Ohensaari ('Bear Island') (Tallgren 1933, 328; Pekkanen 1983, 26; Suvanto 1987, 65, 112-3; Sarmela 1994b, 38-9, 42).

Finnish bear folklore gives women a special relationship with the bear. There is also a clear connection between forest, bear and woman: in folk belief, the 'mistress of the pine/forest' (Hongotar, Osmotar, Kalevatar), the divinity of nature and wilderness, rules over the forest and its 'cattle', i.e., wild animals. Hongotar was also the mother of the bear's family (Haavio 1967, 21; Sarmela 1994a, 213, 222). In Scandinavian mythology and sagas the bear is connected on the one hand with masculine power, strength and courage (e.g., the berserk in the Nordic sagas), on the other with the feminine, particularly with fertility and childbirth (Sarmela 1994b, 43; Jørgensen 2001, 4-8; Mansrud 2002, 90).

Especially in Finland and in the Baltic area, the saints eventually replaced the gods of the old religion. In the same vein, traditions concerning the bear were replaced by Christian tradition: St. Bridget and the Virgin Mary's mother Anna (Annikki) inherited the role of forest guardian spirits 
such as Hongotar. The 'bear's days', karhunpäivät, celebrated in January and July, were also assigned to saints (Haavio 1967, 461-2, 464; Korhonen 1982, 96-121; Sarmela 1994a, 237; Vilkuna 2002, 183-6). In the Finnish tradition the boundary between Christianity and Pre-Christianity was blurred, and the medieval Catholic folk religion took the form in many ways of Christianised sorcery (Sarmela 1994a, 236).

In agriculture-based societies the bear became a harmful animal, which attacked livestock (see Korhonen 1982, 102; Sarmela 1994a, 232; Klemettinen 2002,144 ). Bear remains found in an ecclesiastical context could be seen as representing some form of continuity of the old bear tradition, but they also had a strong connection to the cult of the Christian saints. Bearskins were donated to the parish church in exchange for the saints' protection over the cattle (Korhonen 1982, 103-7, 119; Vilkuna 2002, 183-6). Along with these symbolic meanings, bearskins and furs were also valuable as an item of clothing and were used as blankets (Haavio 1967, 16; Korhonen 1982, 96, 108-9; Laestadius 2000, 195-6).

\section{Bear-Tooth Pendants as Amulets}

An essential issue to discuss in relation to bear-teeth pendants is the role of cosmology and world-view. What, for instance, were the roles of animals in pre-Christian religion and rationality? Folklore offers examples of connections between animals and liminal states - passing 'sacred borders', or rites of passage in birth and death. This is evident in the role of the horse in Nordic mythology (see Carlie 2001, 198, 201; Jennbert 2001, 212, 215; Mansrud 2002, 83-4, 96; also Douglas 1990, 25-36). Animal categorisations differ according to time and space, and thus animals too should understood in a social context (see Shanks \& Hodder 1995). There are certain changes, but the Finnish folk tradition also shows a continuity of beliefs between the pre-Christian and Christian period. The idea of the reincarnation and salvation of the soul, as well as the rites concerning the bear, have probably been passed on from the shamanistic worldview of hunters to later religions. Despite distinct similarities to the later tradition, ideas and conceptions have also changed in many ways once adopted for new cultural contexts, environments and economies. (Siikala 1992, 26-7; Sarmela 1994a, 222-3, 242, 1994b, 92; 2002, 118, 121.)

Ethnological sources indicate that jewellery has sometimes represented status or tribal and ethnic symbolism, as well as being worn as amulets (see Lehtinen 1979, 13, 68, 86; George 1994, 12-13). Hence the boundary 
between jewellery, decorative ornaments and amulets should be considered flexible, and interpretations of their role in the material culture differ in relation to the context of their use. In studies of Nordic Iron Age, for example, finds of single or a few beads in men's graves have been interpreted as amulets; when found in women's graves, often in great numbers, beads are regarded as jewellery and thus as an expression of decorative fashion (see Bye Johansen 2002, 468-85). Moreover, brooches are functional in textiles and garments, and embroidery could be used to strengthen parts of a garment, but both brooches and embroidery are considered to be decorative expressions as well (Ciglis et al. 2001, 29-30; Riikonen 2005, 55-6). Certain garments, such as aprons, which nowadays are often regarded merely as practical protectors over everyday clothes, might originally have been worn as magical garments protecting the wearer's genital area and thus fertility and pregnancy (Riikonen 2005, 57). Medieval popular religion, influenced by the cult of saints, also included the concept of relying on protective magic and amulets, such as saints' relics, or various pendants, made for instance of beads, teeth and coral (Jones 2002, 12-15). Amulets and other protective items also occur later, particularly in Renaissance art (Scarisbrick 1980, 193; Jones 2002, 145, Fig. 2.1).

If we regard organic teeth or claw-pendants and bronze bear-tooth pendants as amulets, it is crucial to bear in mind these ideas and conceptions of traditional folk belief, the metaphorical and metonymical communication of meaning (see for example Leach 1976). It is based on principles of sympathetic magic, similia similibus ('like to like') and pars pro toto ('part for whole') (Vuorela 1981, 262; Talve 1990, 265-6). A metaphorical and metonymical relationship arose when the bear was considered to represent the embodied forest itself. Similar ideas are also present when 'power' or 'mana' (väki) and the characteristics of striking animals were obtained by magic, for instance in the first lines of healing spells: 'I have bear's paws' or 'claws from the hawk' (Harva 1933, 283; Haavio 1967, 19; Siikala 1992, 283). The idea of supernatural power, väki, is one of the key concepts in sorcery.

Bear-tooth pendants as well as other parts of the bear can be regarded as multifunctional items used in different cultural contexts (e.g., Vuorela 1981, 141; Flinckenberg-Gluschkoff \& Garin 1992, 108; Siikala 1992, 242). In addition to protective magic and healing, organic bear-tooth pendants were also connected with hunting magic. When used by hunters bear teeth served as protective items, but in some cases they also indicated hunting skills, as among the men in the Hanty (Ostyak) culture (Flinckenberg-Gluschkoff \& Garin 1992, 143). There are also examples of bear-tooth pendants as im- 
portant grave goods; they were seen as mediating between this world and the 'other side' or the realm of the death. The bear tooth was considered to make the deceased's journey to the 'other world' easier. (d'Anglure 1990, 184, 190.)

The bronze bear-tooth pendants can be connected with the bear and with the forest/wilderness, but another issue is their raw material - bronze. Is it significant that animal symbolism was linked to objects of metal? Metals in fact played an important role as powerful materials in the Finnish folk religion. The concept of 'the power of iron' (raudan väki) has been central in magical rites. An old sword used in war, for instance, could later be used for protective magic (Sarmela 1994a, 213). The sharpness of some metal items, such as knives, axes and nails, was also a powerful symbolic attribute (Talve 1990, 266). Various metals, including copper, bronze (vaski) and tin, were given as offerings to nature spirits (Vuorela 1981, 503). The garments of a shaman or seer (tietäjä) were described as having been made of such metals as vaski or iron (Siikala 1992, 245, 248-9).

Rather than approaching metalworking simply as a technological process, archaeologists have started to address its cognitive aspects as well. The symbolic and ideological dimensions of metals - and one of the most important elements of metalworking, i.e. fire - have come under scrutiny (Brück 1999, 322; see also Talve 1990, 266; Anttonen 1996, 110; Kalninš 1997; Peets 2003). It is noteworthy that the Late Iron Age bronze bear-tooth pendants possess these powerful elements: they are made of metal, and the tip of the pendant is sharp - especially in the youngest types, where the form tends to be more curved, flatter and sharper-pointed, resembling both the tooth and the claw. Furthermore, when the pendants were used as a set - usually twelve were worn around the waist - their higher number may have been seen as a multiplying of their powers (see also Riikonen 2005, 66).

\section{Man and Environment: Nature versus Culture?}

Asplund $(2005,13-30)$ has emphasized the gendered nature of bear-tooth pendants, and the special woman-bear relationship they reveal. He has also pointed out the symbolic defining of boundaries involved and the possible use of pendants as protective devices. According to Riikonen (2005, 31-72), the pendants could possibly also be connected with magical, symbolical and ritual meanings. There are connotations in traditional folk beliefs concerning bears which have to be taken into account in analysing pendants as creators and mediators of cultural meanings. 
According to Finnish folk tradition, the concept of a supernatural and dangerous but at the same time protective power (väki) was associated with cemeteries and their 'inhabitants', the dead, as well as with fire and metal, forest, bear and woman. Certain Christian objects, including the Bible and the Catechism, have also been understood to possess this power (Koponen 1974, 91, 223; Talve 1990, 266-7). Especially powerful was the female lower body, which was linked with 'the other side', or the supernatural world (Apo 1995, 20). In this context, the female väki, force, could be connected with particular gender relations present in agrarian Finnish culture. Folklore materials concerning women's magic rituals and female biology and sexuality establish connections with both protective and destructive forces and powers (Stark-Arola 1998, 118-20). Because of this power, women played a special role in protecting the domestic sphere and cattle against beasts. Female sexuality was seen as a protective power particularly over the bear. Hence the woman's role between culture and nature was seen as a mediating one (Salminen 1914, 2, 7-8; Sarmela 1994a, 234; Apo 1995, 22-5; Stark-Arola 1998, 118-20; Tarkka 1998, 116, 118).

The symbolic role of women became significant when they reached sexual maturity. Particular importance was assigned to certain liminal physiological states - menstruation, marriage and childbirth - all connected with danger and with the sacred. Similar conceptions occurred during the Christian period, as when a postpartum woman had to attend church for a purification ritual. In other words, the new mother was considered polluted as long as she had not been 'churched' (Lehtinen 1979, 13, 29; Anttonen 1996, 142-6; Johansen 2002, 474-5). According to Veikko Anttonen (1996), the folklore evidence suggests that agriculture-based local communities symbolically defined their inner territorial values by means of female rather than male corporeality. He has also noted that corporeality, territoriality and community are cognitive structures, whose symbolic representations lie at the heart of religious or other comparable conceptual systems, regardless of geographical location or historical period. He addresses 'the sacred' (pyhä) as a cultural category rather than a theological concept. The sacred belongs to the same semantic field as the territorial boundary term 'wilderness' (erä), the space outside the inhabited area.

From an archaeological point of view, these notions could also be viewed in connection with wilderness utilisation as a system. This means that the whole area of the Finnish mainland would have been divided into parts, erä being a term for an area belonging to the holdings of the settled areas or small-scale organised bodies. Hence the term erämaa designates 
land that was separate from the inhabited central area (Taavitsainen 1990, 49).

'Wilderness' and 'forest' were understood as critical and dangerous territories, and ritual symbolic actions allowed communication between culture and nature (Anttonen 1996, 117, 139; Tarkka 1998, 95-6; Stark-Arola 2002, 202). Nature and forest had to be tamed and brought under cognitive and symbolic control (Tarkka 1998, 92; see also Anttonen 1994, 24-35). In agrarian societies relationships between man and nature were seen as contradictory. Utilization of the wilderness was important; at the same time, however, there was a need for protection against it (Stark-Arola 2002, 190, 202-3; see also Sarmela 1994a, 233-4). Some scholars have criticized the binary categories of 'nature' and 'culture' implicit in these interpretations, as deriving from a Western worldview and intellectual tradition (Moore 1988, 19; ArwillNordbladh 1998, 25, 253). The idea of a nature/culture dichotomy is in fact complex, with the risk of reducing it to an ecological determinism affecting all cultures (e.g., Jennbert 2001). I suggest that the issue of wilderness and forest in past societies cannot be addressed from the standpoint of a nature/culture dichotomy alone; rather, the focus should be on the analysis of the different relationships taken by wilderness and inhabited spaces in various cultural contexts.

Sarmela (1994a) has taken a different approach to the symbolic relationship of societies with their natural environments (Table 1), presenting the changes or adaptations of societies to their environments as a succession of various forms: from wilderness hunting cultures to swidden farmer cultures, succeeded by cattle-keeping, by organized agrarian societies, and finally by modern societies. These changes are most clearly articulated in attitudes to the bear. In contrast to hunting cultures, for agricultural societies the bear was a harmful predator, killing the cattle and eating the grain. A similar attitude is visible in the bear poetry and bear rituals, which acquired new functions in an agricultural context: to protect the cattle and the whole human sphere.

The bear hunting rites can also be interpreted as a form of tradition applied to those men who crossed the conceptual border between inside and outside, the village and the forest. In the outer domain, the bear as a sacred animal occupied the same position in relation to men that women held toward men in the inner one. Hence men had to cross both borders and maintain life for the sake of the society's flourishing and continuity (Anttonen 1996). In stressing the nature-culture and female-male relationship, however, Anttonen argues that this semiotic model should not be transposed 
to the debate on society, making its male members the primary symbolic objects of the social as well as territorial domain (culture), and women as their secondary objects (nature). Rather, according to Anttonen, in tradition 'the emphasis lies not in male supremacy and female subordination, but in the significance of locality and borders delineating it, and in the social values of the community' (Anttonen 1996, 218).

\begin{tabular}{|l|l|l|l|l|l|}
\hline Culture & $\begin{array}{l}\text { Meaning of } \\
\text { rite }\end{array}$ & $\begin{array}{l}\text { Symbolic } \\
\text { technique }\end{array}$ & Bear image & Rite core & Actors \\
\hline $\begin{array}{l}\text { Nordic } \\
\text { hunting } \\
\text { culture }\end{array}$ & $\begin{array}{l}\text { reincarna- } \\
\text { tion of bear }\end{array}$ & $\begin{array}{l}\text { dealing } \\
\text { with soul }\end{array}$ & $\begin{array}{l}\text { celestial } \\
\text { origin }\end{array}$ & $\begin{array}{l}\text { ritualization } \\
\text { of slaying }\end{array}$ & $\begin{array}{l}\text { hunters } \\
\text { (shaman) }\end{array}$ \\
\hline Bear's clan & $\begin{array}{l}\text { member- } \\
\text { ship } \\
\text { creation }\end{array}$ & $\begin{array}{l}\text { dealing } \\
\text { with } \\
\text { kinship }\end{array}$ & $\begin{array}{l}\text { man's } \\
\text { ancestor }\end{array}$ & $\begin{array}{l}\text { ritualization } \\
\text { of kinship } \\
\text { unity }\end{array}$ & clan \\
\hline $\begin{array}{l}\text { Swidden } \\
\text { culture }\end{array}$ & $\begin{array}{l}\text { repelling } \\
\text { the bear }\end{array}$ & $\begin{array}{l}\text { dealing } \\
\text { with } \\
\text { powers }\end{array}$ & evil origin & $\begin{array}{l}\text { ritualization } \\
\text { of repelling }\end{array}$ & sorcerer \\
\hline $\begin{array}{l}\text { Peasant } \\
\text { culture }\end{array}$ & $\begin{array}{l}\text { destruction } \\
\text { of bear }\end{array}$ & $\begin{array}{l}\text { dealing } \\
\text { with fear }\end{array}$ & $\begin{array}{l}\text { destructive } \\
\text { animal }\end{array}$ & $\begin{array}{l}\text { ritualization } \\
\text { of human } \\
\text { activity }\end{array}$ & $\begin{array}{l}\text { hunt master } \\
\text { community }\end{array}$ \\
\hline $\begin{array}{l}\text { Industrial } \\
\text { culture }\end{array}$ & $\begin{array}{l}\text { killing } \\
\text { experience }\end{array}$ & $\begin{array}{l}\text { dealing } \\
\text { with fire- } \\
\text { arms }\end{array}$ & $\begin{array}{l}\text { beast of } \\
\text { prey }\end{array}$ & $\begin{array}{l}\text { killing tech- } \\
\text { nology }\end{array}$ & $\begin{array}{l}\text { heroic } \\
\text { hunter }\end{array}$ \\
\hline $\begin{array}{l}\text { Postlocal } \\
\text { culture }\end{array}$ & $\begin{array}{l}\text { Bear } \\
\text { experience } \\
\text { (virtual) }\end{array}$ & $\begin{array}{l}\text { dealing } \\
\text { with man's } \\
\text { conscious- } \\
\text { ness }\end{array}$ & $\begin{array}{l}\text { member } \\
\text { of nature }\end{array}$ & $\begin{array}{l}\text { ritualization } \\
\text { of con- } \\
\text { sciousness } \\
\text { technology }\end{array}$ & $\begin{array}{l}\text { conscious- } \\
\text { ness techni- } \\
\text { cian, meri- } \\
\text { tocracy }\end{array}$ \\
\hline
\end{tabular}

Table 1. Relationship between man and bear in different cultural contexts according to Matti Sarmela (1994a, 243).

\section{The Wilderness as a Resource in the Late Iron Age}

From the point of view of cognitive archaeology, one of the central questions concerning the use and possible meanings of bronze bear-tooth pendants in the Late Iron Age is the worldview and rationality of the era. Connected with these questions is that of the relationship between communities, or the human sphere, and nature/wilderness. We thus need to take a look at the socio-economic, political and ideological processes, whether local or involving the whole the Baltic Sea area, which affected the symbolic sphere in the societies of Late Iron Age Finland. In this analysis I focus on two particular aspects of the wilderness and forest: first of all as sources of 
utility, secondly as parts of a cognitive system of beliefs, ideas and concepts. Both aspects are traced from the prehistorical period to the present. When viewed through Karelian folk poetry and tradition, ideas connected with the wilderness and forest can be seen as a complex phenomenon combining various, even contradictory elements (Tarkka 1994, 92). Importantly, the cognitive complexity of the forest/wilderness phenomenon is part of the agriculture-based worldview, not merely of hunting cultures (Ylimaunu $2002,118,121)$. Even if the world-view changes, communication with the natural environment remains.

Forest/wilderness is an important element of various resources in Finland. Jussi-Pekka Taavitsainen (1990, 48-9) has noted that the practice of wilderness hunting and resource utilisation described in written sources from the medieval to modern periods provides a basis for a relevant model for the study of Iron Age conditions. Various forms of utilisation of wilderness resources were important: game-hunting and fur-trapping, fishing, timbering, tar and charcoal-burning, slash-and-burn cultivation, and the gathering of lake-ore and iron smelting (Taavitsainen 1990, 49; 1994, 187-207; Kumpulainen 2001, 2, 4). Wilderness utilisation intensified during the Viking Period. Taavitsainen $(1990,112)$ has suggested that possible reasons for this change were related to trade and the means of livelihood of the indigenous population, which caused a process of colonisation or transition from transhumance to permanent settlement. He has pointed out internal factors present in southwest Finland,, such as social change, population growth and technological innovations, along with external ones such as political changes and developments in trade (Taavitsainen 1990, 48, 112-13; see also Meinander 1980, 12-13). Taavitsainen argues that these push-and-pull factors - as in the case of colonisation - are all interlinked to such a high degree that their classification is difficult (Taavitsainen 1990, 112).

It is clear that during the last centuries of the prehistoric era the economic development of the Finnish area was stimulated by trade relations. In particular Viking Age silver coins indicate the presence of important trading links to neighbouring areas as well as Continental Europe. Coins found in the Nordic countries show that the earliest imported silver coins were 'abbāsid sāmānid coins, but that these were gradually replaced in popularity by Western European ones (Talvio 2002). Central to the increase in economic activity was the utilisation of local and international waterways as well as overland routes.

During the Viking Age, the Baltic trade route linking Western and Eastern Europe passed close to the southern coast of the Finnish mainland. The 
origin of the Häme Oxen Road from the Turku region to that of Lake Vanaja in Häme is closely connected with this route and with Viking Age barter trade, particularly during the Birka period (800-975 CE) (Masonen 1989, 193; see also Salo 1984, 14). The most important reason for the intensification of wilderness utilisation was probably the demand for furs. In the Finnish area the wilderness could be seen as a source of wealth, and furs in particular were among the most marketable trade articles (Kivikoski 1960, 33; Masonen 1989, 85, 130-1). Väinö Voionmaa (1947, 24-32) has suggested that during the Late Iron Age an economy based on subsistence-type wilderness utilisation was transformed into one based on commercial utilisation, in which the fur trade was prominent (see also Taavitsainen 1990, 113). The fur-hunting economy is often related not only to foreign trade but also to taxation (e.g., Kerkkonen 1953, 1-27; Petré 1980, 8, 12-3; Taavitsainen 1990, 49-50; Jutikkkala \& Pirinen 1999, 21). Silver hoards found on the Finnish mainland have also been interpreted as indicators of international trade and of an organized fur trade (Saksa 1998, 204; Talvio 2002, 119-20).

The exploitation of wilderness resources was carried out by individual farming households or families. Expeditions to obtain furs were made by wilderness-hunting peasants (Tallgren 1933; Kaukiainen 1980, 51; Taavitsainen 1990, 50). It has also been suggested that there were separately built farms for trade in the wilderness regions (Lehtosalo-Hilander 1982, 329; Taavitsainen 1994, 201). According to some medieval written sources there were wealthy old wilderness-hunting households, as in the Sääksmäki parish in Häme. Social status and property were largely based on wilderness utilisation (Suvanto 1995, 141). In particular fur-trapping expeditions and the establishment of wilderness households provided wealth, but it was the already wealthy households that benefitted most (Taavitsainen 1994, 187-207; Kumpulainen 2001, 2, 4, 114). Archaeological material from the Luistari cemetery in Eura reveals the increasing role of hunting in Late Iron Age societies. Pirkko-Liisa Lehtosalo-Hilander $(2000,204)$ has linked this with the increased importance of wilderness utilisation and especially the fur-hunting economy. Rather than a cultivation economy, the prosperity of some members of the community was based on utilizing the wilderness and on trading in the products of this utilization.

The fur-based economy must have had an effect on the social position of women. On the basis of the archaeological record, in particular the rich female inhumation graves at the Luistari cemetery, Lehtosalo-Hilander has outlined a picture of women in the Late Iron Age as active and equal to men (Lehtosalo-Hilander 2000, 307). Folklore in part supports this idea of the 
strong woman, the farmwife, with responsibility over the domestic sphere. Not only the household but also the products of male labour were in the hands of women, who managed the household during the men's absence (Apo 1995, 19; Lehtosalo-Hilander 2000). The archaeological record, particularly from the eleventh century and the Crusade Period, indicates the increasing role of women and more broadly of the family. There are many examples of wealthy women's graves, of double graves with a man and woman in the same grave, and of some rich child burials (see LehtosaloHilander 2000, 307; 2001, 94).

\section{Conclusions}

The bear-tooth pendants are a symbolic expression of the pre-Christian worldview and rationality, and represent the symbolic interplay between a culture and its environment. This interplay, however, cannot by described in terms of a simplistic conception of nature and culture in binary opposition. The bear's tooth negotiated the relationship between communities and wilderness within a certain social context. One important aspect of this interplay involves for example the different roles of animals, whether domesticated or wild, and animal symbolism. Animals may have played a significant role in Iron Age Finnish communities, not only from the economic-functional point of view but also in the mythology and in cosmological conceptions. In addition to certain artefacts, mortuary practices may also provide evidence of the utilisation of animal symbolism. It seems possible that the use of bronze bear-tooth pendants as mediating symbols was based on the old bear mythology.

The bear-tooth pendants may have functioned as a form of symbolic communication between the community, i.e. the 'human sphere', and 'nature'. They are related to the utilization of the wilderness. I argue that these pendants created metaphoric and metonymic relationships between the bear, the wilderness and those who wore the pendants. In the Finnish folk tradition the bear's tooth represents the whole bear, just as the bear represents the whole of the forest and the wilderness. There is a notable association between the bear and a woman. Whether the bronze bear-tooth pendants were gender-limited and intended only for women is unclear, but archaeological evidence from Finnish and Latvian sites show that this may be a possible inference.

The most recent interpretations of the bear-tooth pendants have also stressed gender aspects. Their meaning has been explained as related to 
fertility and sexuality. Henrik Asplund (2005, 13-30) has considered this relationship to be the likely reason why the pendants were worn on the waist, close to the stomach and the genitalia. Hence these pendants could be seen as part of symbolic definition and protection. Jaana Riikonen (2005, 31-72) has discussed the different functions of ornaments, their magical and symbolic functions as well as aesthetic and practical ones. She suggests that the idea of the bear-tooth pendants and other pendants and cloths worn on the waist could be connected with protective magic and rituals, possibly even with women's role in fertility rites. These assumptions do not exclude another possibility, which is argued in the present article.

I suggest that the bear-tooth pendants can also be regarded as symbolic expressions of control over the forest/wilderness. The symbols - the beartooth or claws in cast bronze - could have been worn by some women, based on mythological conceptions and beliefs. Control over the wilderness here means not only cognitive control, such as as magical rites and ritual behaviour, but crucially also the utilization of wilderness, especially hunting activities. The products of the wilderness were the most important resource and source of wealth in Late Iron Age trade. In particular the fur-based economy, from wilderness fur-trapping to foreign trade, became more important during the Viking Age. This increased economic activity evidently at the same time created social pressures and conflicts, as well as providing opportunities to maintain and strengthen positions of power. It is probable that at least some farming communities of southwest Finland became more interested in controlling the fur trade. Certain families or houses may have been important agents in the organization of the fur trade. Some members of agriculture-based communities could also have been active in fur-trapping. There is evidence of this in the graves of the Luistari burial ground in Eura. It is possible that the regional distribution of the bronze bear-tooth pendants indicates co-operation and unity between houses or villages in southwest Finland. The need for material identification may have been actualized on a visible yet symbolic level.

Another issue concerning the use of bear-tooth pendants is the impact of Christianity in Late Iron Age Finland and its effect on the various symbolic meanings of contemporary ornaments. The neighbouring areas had already converted to Christianity at the end of the Viking Age. On the Finnish mainland, in contrast, the Late Viking Age and in the 'Crusade Period' in the eleventh century was a transition period, bringing changes and external influences. The archaeological and folkloristic evidence, however, also demonstrates continuities in tradition from the pre-Christian to 
the Christian period. I am not suggesting that the bear-tooth pendants, as a form of symbolic expression, represented some form of opposition to Christianity, although from a modern Christian point of view they can be understood as pagan symbols. Rather, I suggest that interpretation of the bear-tooth pendants as pagan emblems is not a relevant explanation for their occurrence.

Bibliography

Unpublished sources

Hukantaival, Sonja

2006 'Sillä noita ei sellaisen kynnyksen yli pääse!' Rakennusten ritualistiset kätköt. MA thesis, Department of Archaeology, University of Turku.

\section{Jäkärä, Tiina}

1997 Turun Kirkkomäen ja Raision Ihalan Vanhan kansakoulun kalmistojen hautarakenteet. MA thesis, Department of Archaeology, University of Turku.

\section{Kivisalo, Nora}

2006 Pronssiset karhunhammasriipukset nuoremmalla rautakaudella. Esinetutkimuksesta kognitiivisen arkeologian kysymyksiin. MA thesis, Department of Archaeology, University of Turku.

\section{Koivisto, Leena}

1991 Maarian Taskula ja Virusmäki: kaksi nuoremman rautakauden kalmistoa Turussa. MA thesis, Department of Archaeology, University of Turku.

\section{Kumpulainen, Miikka}

2001 Elämää oravimetsissä. Eränkäynti ja eräsija, esimerkkipaikkakuntana Pihtipudas. MA thesis, Department of Archaeology, University of Turku.

\section{Tupala, Ulla}

1999 Eläinuhreja vai teurasjätettä. Euran Luistarin rautakautisen ruumiskalmiston eläinluumateriaalin lähdekriittistä tarkastelua. MA thesis, Department of Archaeology, University of Turku.

\section{Vuorinen, Juha-Matti}

2003 Rakennus sosiaalisen toiminnan näyttämönä. Rakentaminen Raision Ihalan Mullissa rautakauden lopulla ja varhaisella keskiajalla. MA thesis, Department of Archaeology, University of Turku. 


\section{Literature}

\section{Anttonen, Veikko}

1996 Ihmisen ja maan rajat. 'Pyhä' kulttuurisena kategoriana. (Suomalaisen Kirjallisuuden Seuran Toimituksia 646.) Helsinki: Suomalaisen Kirjallisuuden Seura.

1994 Erä-ja metsäluonnon pyhyys. - Pekka Laaksonen \& Sirkka-Liisa Mettomäki (eds) Metsä ja metsänviljaa, 24-35. (Kalevalaseuran vuosikirja 73.) Helsinki: Suomalaisen Kirjallisuuden Seura.

\section{d'Anglure, Saladin B.}

1990 Nanook, super-male: the polar bear in the imaginary space and social time of the Inuit of the Canadian Arctic. - R. G. Willis (ed.) Signifiying animals: human meaning in the natural world, 173-195. London: Unwin Hyman.

\section{Apo, Satu}

1995 'Ex cunno väki tulee.' Fyysiseen naiseuteen liittyvä ajattelu suomalais-karjalaisessa perinteessä. - Satu Apo, Naisen väki. Tutkimuksia suomalaisten kansanomaisesta kulttuurista ja ajattelusta, 11-49. Helsinki: Hanki ja jää.

\section{Arwill-Nordbladh, Elisabeth}

1998 Genuskonstruktioner i nordisk vikingatid förr och nu. Göteborg: Göteborgs universitet.

\section{Asplund, Henrik}

2005 The bear and the female. Bear-tooth pendants in Late Iron Age Finland. - Sari Mäntylä (ed.), Rituals and relations. Studies on society and material culture of the Baltic Finns, 13-30. (Suomalaisen Tiedeakatemian toimituksia. Humaniora 336.) Helsinki: Finnish Academy of Science and Letters.

\section{Bennett, Agneta}

1987 Graven - Religiös och social symbol. Strukturer i folkvandringtidens gravskick i Mälarområdet. Theses and Papers in North-European Archaeology, 18. Stockholm: University of Stockholm, Institute of Archaeology.

\section{Brück, Joanna}

1999 Ritual and Rationality: Some Problems of Interpretation in European Archaeology. - European Journal of Archaeology, 2 (3), 313-44.

\section{Bye Johansen, Lise-Marie}

2002 Perler i jernalder - kilde til mote i kvinnegraver og magi i mannsgraver? Mellom himmel og jord. Foredrag et seminar om religionsarkeologi segran 31. januar-2. Februar 2002. - OAS 2, 468-90. 


\section{Carlie, Anna}

2001 Settlement Material as sources for Studying Pagan Cult a Question of Reading 'Hidden' Structures? Scandinavian Archaelogical Practise - in Theory. - OAS 1, 198-210.

Ciglis, Jānis \& Sandra Zirne \& Irita Žiere

2001 The Livs in Antiquity. Riga: Latvijas Vēstures muzejs.

\section{Douglas, Mary}

1990 The pangolin revisited: a new approach to animal symbolism. - R. G. Willis (ed.), Signifying animals: human meaning in the natural world, 25-36. London: Unwin Hyman.

\section{Edsman, Carl-Martin}

1994 Jägaren och makterna. Samiska och finska björnceremonier. Uppsala: Dialekt- och folk-minnesarkivet.

\section{Eldorhagen, Marianne}

2001 Style and Symbolism in Nordic Animal Art. Scandinavian Archaelogical Practise - in Theory. - OAS 1, 180-5.

\section{Flinckenberg-Gluschkoff, Marianna \& Nikolai Garin}

1992 Ugrien mailla. Suomalaisten tutkimusmatkailijoiden jalanjäljillä Obvirralta Uralille. Helsinki: Otava.

\section{Formisto, Tarja}

1996 Osteological Analyses. - Paula Purhonen (ed.), Vainionmäki - a Merovingian Period Cemetery in Laitila, Finland, 81-7. Helsinki: National Board of Antiquities.

\section{George, Beate}

1994 Liv, hälsa, skönhet - Egyptiska smycken. (Medelhavsmuseet, Skrifter 19.) Stockholm: Medelhavsmuseet.

\section{Haavio, Martti}

1967 Suomalainen mytologia. Porvoo: WSOY.

\section{Harva, Uno}

1933 Altain suvun uskonto. Porvoo: WSOY.

\section{Herva, Vesa-Pekka \& Timo Ylimaunu}

2004 Modernisaation jäljet pohjoisessa. Tornion kaupunkiarkeologiset kaivaukset 1996-2002. - SKAS 1/2002, 20-4.

\section{Hiekkanen, Markus}

1988 Polvesta polveen täällä. Espoon kirkon esiinkaivettua menneisyyttä. Espoo: Espoon seurakunnat.

1997 Historiallisen ajan (AD 1150/1200) luuaineisto luonnontieteiden 
tutkimuskohteina. -Heikki Vuorinen (ed.), Vanhojen luiden kertomaa, 62-73. Helsinki: Yliopistopaino.

\section{Hårding, Barbro}

2002 Människan ach djuren - om dagligt liv och begravningsritualer under järnåldern. - Acta Antiqua Ostrobotniensia, 213-22.

\section{Jennbert, Kristina}

2001 Ambiguous Truths? - People and Animals in Pre-Christian Scandinavia. Scandinavian Archaelogical Practise - in Theory. - OAS 1, 212-30.

\section{Jones, Malcolm}

2002 The Secret Middle Ages. Stroud: Sutton.

Jørgensen, L. B.

2001 Bjørnekrigere. - Spor 1, 4-8.

\section{Jutikkala, Eino \& Kauko Pirinen}

1999 Suomen historia. Asutuksen alusta Ahtisaareen. Helsinki: WSOY. 5th edition.

\section{Kalninš, Daumants}

1997 Elements of myth in early Latgallian female burials from viewpoint of a jewellery smith. - Mits un Metal, Cesis 10.-13.09.1997, 38-43.

Katalog der Ausstellung zum X. archäologischen Kongress in Riga 1896.

1896 Riga: W. F. Häcker.

\section{Kaukiainen, Yrjö}

1980 Suomen asuttaminen. - Eino Jutikkala \& Yrjö Kaukiainen \& SvenErik Åström (eds), Suomen taloushistoria 1. Agraarinen Suomi, 11-145. Helsinki: Tammi.

\section{Kerkkonen, Gunvor}

1953 Hiisibygderna såsom pälsvarustaplar för handeln vid Finska vikens skeppsled. - Historisk Tidskrift för Finland 38, 1- 27.

\section{Kivikoski, Ella}

1951 Suomen rautakauden kuvasto II. Porvoo, Helsinki: WSOY.

1965 Magisches Fundgut aus finnischer Eisenzeit. - Suomen Museo LXXII, 22-35.

1971 Turun seudun esihistoria kivikaudesta noin vuoteen 1150. - Ella Kivikoski \& C. J. Gardberg (eds), Turun kaupungin historia kivikaudesta vuoteen 1366, 1-110. Turku: Lounaisrannikko.

\section{Klemettinen, Pasi}

2002 Kurkistuksia karhun kulttuurihistoriaan. - Henni Ilomäki \& Outi 
Lauhakangas (eds), Eläin ihmisen mielenmaisemassa, 134-73. Helsinki: Suomalaisen Kirjallisuuden Seura.

\section{Koponen, Onni E.}

1974 Pielisen museon kertomaa. Pielisjärven oloista lähinnä 1800-luvulla. (Joensuun museon julkaisuja numero 4.) Joensuu: Joensuun museo.

\section{Korhonen, Teppo}

1982 Saaliseläimen taljan ja kotieläimen vuodan käyttö uhreina. - Suomen Antropologi 3, 96-121.

\section{Laestadius, Lars Levi}

2000 (1840-1845) Lappalaisten mytologian katkelmia. Edited by Juha Pentikäinen. (Tietolipas 170.) Helsinki: Suomalaisen Kirjallisuuden Seura.

\section{Leach, Edmund R.}

1976 Culture and Communication: the Logic by which Symbols are Connected. Cambridge: Cambridge University Press.

\section{Lehtinen, Ildikó}

1979 Naisten korut Keski-Venäjällä. Helsinki: Museovirasto.

\section{Lehtosalo-Hilander, Pirkko-Liisa}

1982 Luistari II. The Artefacts. (Suomen Muinaismuistoyhdistyksen Aikakauskirja 82:2.) Helsinki: Suomen muinaismuistoyhdistys.

1992 Kvinnosmycken med magisk innebörd. - Roesdahl, Else (ed.), Viking og Hvidekrist. Norden og Europa 800-1200, 290. København : Nordisk Ministerråd.

2000 Kalastajia ja kauppanaisia. Eura: Euran kunta.

\section{Leppäaho, Jorma}

1937 Savukosken Mukkalan lappalaiskalmisto. - Kotiseutu 3-4, 134-44.

\section{Luik, Heidi}

1998 Ovaalsõled eestis - importesemed mitmest piirkonnast. - Eesti Arheoloogia Ajakiri, 2, 3-20.

2001 Luuesemed Kuusalu Pajulinnast ja asulatest. - Eesti Arheoloogia Ajakiri $5 / 1,3-36$.

\section{Mansrud, Anja}

2002 Dyrebein i graver - en kilde til jernalderens kult og forestillingsverden. Mellom himmel og jord. - OAS 2, 82-111.

\section{Masonen, Jaakko}

1989 Hämeen Härkätie. Synty ja varhaisvaiheet. (Tiemuseon julkaisuja 4.) Helsinki: Valtion painatuskeskus.

Meinander, C. F.

1980 The Finnish society during the 8th-12th centuries. - Fenno-Ugri et Slavi 1978. Helsingin yliopiston arkeologian laitos, moniste n:o 22, 7-13. 


\section{Miettinen, Timo}

2006 Karhukultin juuret uskontoarkeologisen tutkimuksen valossa. - Clive Tolley (ed.), The Roots of the Bear Cult in the Light of Research into the Archaeology of Religion. Karhun kannoilla - In the Footsteps of the Bear, 117-26. Pori: Turun yliopisto, kulttuurintuotannon ja maisemantutkimuksen laitos/Satakunnan museo.

\section{Moore, Henrietta L.}

1988 Feminism and Anthropology. Cambridge: Polity Press.

Nirvi, R. E.

1982 Petojen nimitykset kosinta- ja hääsanastossa. (Suomi 123:3.) Helsinki: Suomalaisen Kirjallisuuden Seura.

\section{Näsström, Britt-Mari}

2002 Vid gudarnas bord - heliga platser och offerplatser i fornskandinavisk religion. Mellom himmel og jord. - OAS 2, 52-67.

\section{Paavola, Kirsti}

1988 Domus pro templo-Hailuodon kirkon varhaisvaiheet. - Kyösti Julku \& Reija Satokangas, Reija (eds), Hailuodon keskiaika, 9-34. (Studia Historica Septentrionalia 15.) Oulu: Oulun yliopisto.

\section{Peets, Jüri}

2003 The Power of Iron. Iron Production and Blacksmithy in Estonia and Neighbouring Areas in Prehistoric Period and the Middle Ages. (Muinasaja teadus 12.) Turku: University of Turku.

\section{Pekkanen, Tuomo}

1983 Vanhin kirjallinen tieto suomalaisista. - Suomalais-ugrilaisen seuran aikakauskirja, 173-185.

\section{Pentikäinen, Juha}

2005 Karhun kannoilla. Metsänpitäjä ja mies. Helsinki: Etnika Oy.

\section{Petré, Bo}

1980 Björnfällen i begravningsritualen - statusobjekt speglande regional skinnhandel? - Fornvännen 1, 5-14.

\section{Pihlman, Sirkku}

2005 Beziehungen mit den Liven? Gedanken über die kontaktfelder der Raisiobewohner am ende der prähistorischen zeit. - Sari Mäntylä (ed.), Rituals and relations. Studies on society and material culture of the Baltic Finns, 207-23. (Suomalaisen Tiedeakatemian toimituksia. Humaniora 336.) Helsinki: Finnish Academy of Science and Letters.

Pukkila, Jouko

1999 Rahoista rautanauloihin. - SKAS 4, 37-42. 


\section{Purhonen, Paula}

1998 Kristinuskon saapumisesta Suomeen. Uskontoarkeologinen tutkimus. - Suomen Muinaismuistoyhdistyksen Aikakauskirja 106.

\section{Riikonen, Jaana}

2005 Iron Age aprons from southwest Finland. And other cloths and pendants worn on the waist. - Sari Mäntylä (ed.), Rituals and relations: Studies on society and material culture of the Baltic Finns, 31-72. (Suomalaisen Tiedeakatemian toimituksia. Humaniora 336). Helsinki: Finnish Academy of Science and Letters.

\section{Saksa, Aleksandr}

1998 Rautakautinen Karjala. Muinais-Karjalan asutuksen synty ja varhaiskehitys. (Studia Carelica Humanistica 11.) Joensuu: University of Joensuu.

\section{Salminen, Väinö}

1914 Eräs karhupeijaisia ja karhurunoja sisältävä vanha muistiinpano. - Suomalais-ugrilaisen Seuran Toimituksia XXXV:12.

\section{Salo, Unto}

1984 Kaupunkilaitoksen esivaiheista Suomessa. Historiallisen ajan arkeologia Suomessa, 8-25. (Raportteja 6.) Turku: Turun maakuntamuseo.

2006 Karhun kämmen ja karhun kynsi. Karhun jälkiä Suomen esihistoriassa. - Clive Tolley (ed.), The roots of the bear cult in the light of research into the archaeology of religion. Karhun kannoilla - In the footsteps of the bear, 167-182. Pori: Turun yliopisto, kulttuurintuotannon ja maisemantutkimuksen laitos/Satakunnan museo.

\section{Sarkamo, Jaakko}

1970 Retulansaaren uhriröykkiö. - Suomen Museo, 35-47.

1984 Retulansaaren 'uhriröykkiö'. - Pirkko-Liisa Lehtosalo-Hilander, Keski- ja myöhäisrautakausi, 306. Suomen esihistoria. Suomen historia I. Espoo: Weilin + Göös.

\section{Sarmela, Matti}

1972 Karhunpeijaisten arvoitus. - Kotiseutu 4-5, 164-170.

1994a Karhu ihmisen ympäristössä. - Pekka Laaksonen \& Sirkka-Liisa Mettomäki (eds), Kolme kovaa sanaa. Kirjoituksia kansanperinteestä, 209-50. (Kalevalaseuran vuosikirja 71.) Helsinki: Suomalaisen Kirjallisuuden seura.

1994b Suomen perinneatlas. Suomen kansankulttuurin kartasto 2. (Suomalaisen Kirjallisuuden Seuran Toimituksia 587.) Helsinki: Suomalaisen Kirjallisuuden seura.

2002 Meritokratian eläinkuvia. - Henni Ilomäki \& Outi Lauhakangas (eds), Eläin ihmisen mielenmaisemassa, 174-92. Helsinki: Suomalaisen Kirjallisuuden Seura.

\section{Scarisbrick, Diana}

1980 Renaissance Jewelry. - Anne Garside (ed.), Jewelry: Ancient to Modern, 176-215. New York: The Viking Press. 


\section{Serning, Inga}

1965 Sacrificial Sites, Dwelling Sites or Trading depots? - Hunting and Fishing, 387-96. Luleå: Norrbottens museum.

\section{Shanks, Michael \& Ian Hodder}

1995 Processual, postprocessual and interpretive archaeologies. - Ian Hodder \& Michael Shanks \& Alexandra Alexandri \& Victor Buchli \& John Carman \& Jonathan Last \& Gavin Lucas (eds), Interpreting Archaeology: Finding Meaning in the Past, 3-29. London: Routledge.

\section{Siikala, Anna-Leena}

1992 Suomalainen šamanismi: mielikuvien historiaa. Helsinki: Suomalaisen Kirjallisuuden Seura.

\section{Šnē, Andris}

2005 Archaeological evidence of social relations and power in the late prehistoric societies of the Livs. - Sari Mäntylä (ed.), Rituals and relations: Studies on society and material culture of the Baltic Finns, 169-185. (Suomalaisen Tiedeakatemian toimituksia. Humaniora 336.) Helsinki: The Finnish Society for Arts and Letters.

\section{Stark-Arola Laura}

1998 Lempi, tuli ja naisen väki. Dynamistisista suhteista suomalais-karjalaisessa taikuudessa ja kristinuskossa. - Jyrki Pöysä \& Anna-Leena Siikala (eds), Amor, Genus E familia: Kirjoituksia kansanperinteestä, 11735. (Tietolipas 158.) Helsinki: Suomalaisen Kirjallisuuden Seura.

2002 Pyhä raja ja pyhä keskus. Rituaalimallit ortodoksisen Karjalan kansanuskossa. - Pyhän perintö, 181-219. (Kalevalaseuran vuosikirja 79-80.) Helsinki: Suomalaisen Kirjallisuuden Seura.

\section{Suhonen, Mervi}

1998 A lead-bronze ingot from Mulli at Ihala in Raisio. - Fennoscandia archaeologica XV, 71-6.

\section{Suvanto, Seppo}

1987 Knaapista populiin. Tutkimuksia erilaistumisesta Satakunnan talonpojistossa vuosina 1390-1571. (Historiallisia Tutkimuksia 142.) Helsinki: Suomen Historiallinen Seura.

1995 Yksilö myöhäiskeskiajan talonpoikaisyhteiskunnassa. Sääksmäen kihlakunta 1400-luvun alusta 1570-luvulle. (Historiallisia Tutkimuksia 193.) Helsinki: Suomen Historiallinen Seura.

\section{Taavitsainen, Jussi-Pekka}

1990 Ancient hillforts of Finland: Problems of analysis, chronology and interpretation with special reference to the hillfort of Kuhmoinen. Suomen Muinaismuistoyhdistyksen Aikakauskirja 94.

1994 Kaskeaminen ja metsästys erämailla. - Pekka Laaksonen \& Sirkka- 
Liisa Mettomäki (eds), Metsä ja metsänviljaa, 187-207. (Kalevalaseuran vuosikirja 73.) Helsinki: Suomalaisen Kirjallisuuden Seura.

\section{Tallgren, A. M.}

1933 Hiisi ja moisio: Yritys muinaissuomalaisen asutus- ja yhteiskuntahistorian selvittämiseksi. - Virittäjä, 319-31.

Talve, Ilmar

1990 (1979) Suomen kansankulttuuri. (Suomalaisen Kirjallisuuden Seuran toimituksia 514.) Helsinki: Suomalaisen Kirjallisuuden Seura.

Talvio, Tuukka

1987 Coins and finds in Finland AD 800-1200. (Iskos 12.) Helsinki: Suomen muinaismuistoyhdistys.

\section{Tarkka, Lotte}

1994 Metsolan merkki. Metsän olento ja kuva vienalaisrunostossa. - Pekka Laaksonen \& Sirkka-Liisa Mettomäki (eds), Metsä ja metsänviljaa, 56-102. (Kalevalaseuran vuosikirja 73.) Helsinki: Suomalaisen Kirjallisuuden Seura.

1998 Sense of the Forest: Nature and gender in Karelian Oral Poetry. - Satu Apo \& Aili Nenola \& Laura Stark-Arola (eds), Gender and Folklore: Perspectives on Finnish and Karelian Culture, 92-142. Helsinki: Suomalaisen Kirjallisuuden Seura.

\section{Tõnisson, Evald}

1974 Die Gauja-Liven und ihre materielle kultur (11Jh. - Anfang 13. Jhs.). Ein Beitrag zur Ost-Baltischen Frühgeschihte. Tallinn: Eesti Raamat.

\section{Uino, Pirjo}

1997 Ancient Karelia. Archaeological studies. Muinais-Karjala. Arkeologisia tutkimuksia. Suomen Muinaismuistoyhdistyksen Aikakauskirja 104. Helsinki.

Vahter, Tyyni

1932 Kaatterit. - Suomen Museo XXXVIII-XXXIX, 40-9.

\section{Valonen, Niilo}

1958 Turun viemärikaivantolöydöistä. Turun kaupungin historiallinen museo. Vuosijulkaisu 20-21, 1956-1957, 12-110

\section{Vilkuna, Kustaa}

2002 (1950) Vuotuinen ajantieto. Helsinki: Otava.

\section{Voionmaa, Väinö}

1947 Hämäläinen eräkausi. Porvoo: WSOY.

\section{Vuorela, Toivo}

1981 Kansanperinteen sanakirja. Helsinki: WSOY. 


\section{Ylimaunu, Juha}

2002 Elinkeinot ihmisen ja eläimen suhteen muokkaajana. - Henni Ilomäki, \& Outi Lauhakangas (eds), Eläin ihmisen mielenmaisemassa, 115-33. Helsinki: Suomalaisen Kirjallisuuden Seura.

\section{Zachrisson, Inger}

2002 Samiska offerfynd. - Anita Knape (ed.), Guldets magi i saga och verklighet, 91-3. Stockholm: Statens Historiska Museum.

\section{Zachrisson, Inger \& Elisabeth Iregren}

1974 Lappish Bear Graves in Northern Sweden. An Archaeological and Osteological Study. - Early Norrland 5.

\section{Zarina, Anna}

1988 Lìbiešu apǵērbs 10.-13.gs. Zinātne: Rīga. 
